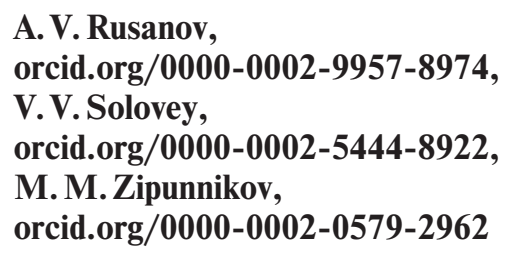

\title{
IMPROVEMENT OF THE MEMBRANE-FREE ELECTROLYSIS PROCESS OF HYDROGEN AND OXYGEN PRODUCTION
}

Renewable energy sources provide an unstable energy flow to the units of an autonomous energy complex. Therefore, in order to use the electrolyzer as an element of the considered complex, it is necessary to determine the optimal range of changes in the current density and evaluate the effect of operating characteristics of the electrolysis process on the evolution of $\mathrm{H}_{2}\left(\mathrm{O}_{2}\right)$ when the electrolyzer power supply is disconnected for 1-3 seconds against the background of a continuous base current level.

Purpose. The main purpose of the research is to determine the rational range of changes in the current density supplied to a monopolar membrane-free high-pressure electrolyzer, as well as to determine the effect of a discrete current supply on electrochemical reactions during electrolysis.

Methodology. Comprehensive studies on the electrochemical processes of water decomposition in alkaline electrolyte with the formation of hydrogen and oxygen in an experimental construction make it possible to cyclically supply power to the electrolyzer with visual control of the considered processes.

Findings. The technology of cyclic generation of hydrogen and oxygen, which eliminates the need to use separating ion-exchange membranes, is considered. A rational range of changes in the current density on a membrane-free monopolar high-pressure electrolyzer with the usage of electrodes made of metals with variable valence is established. The influence of the discrete supply of electrical energy to the electrolysis cell is determined depending on the electrochemical reactions occurring on the active iron electrode. Theoretical values of the voltage of the oxidation and reduction of the iron electrode active mass, as well as the voltage on the half-cycle of hydrogen evolution during the electrolysis of water, are calculated.

Originality. An increase in the blackout time from 1 to $3 \mathrm{~s}$ leads to a corresponding increase in time of the oxidation process on the hydrogen half-cycle by a factor of 2.4. In addition, the total amount of hydrogen (oxygen) released during the corresponding half-cycles remains unchanged and amounts to $V_{\mathrm{H}_{2}}=15 \mathrm{ml}\left(V_{\mathrm{O}_{2}}=7.5 \mathrm{ml}\right)$.

Practical value. The optimal range of current density for the operation of a membrane-free high-pressure electrolyzer is in the range of 200-400 A/ $\mathrm{m}^{2}$. Under such conditions, an intense redox process of the iron electrode active mass occurs. Electrical energy consumption in this case is in the range of $3.9-4.1 \mathrm{~kW} \cdot \mathrm{h} / \mathrm{m}^{3}$. An experimental study on the electrolyzer discrete power supply effect on its ability to generate gas is carried out. This makes it possible to supply electrical energy to the electrolysis cell directly from the primary energy source (sun, wind) as part of the energy technology complex.

Keywords: electrolyzer, hydrogen, oxygen, electrochemical reaction, current, electrode

Introduction. Energy development is based on the hypothesis of the evolutionary nature of technological changes occurring during the production, distribution and consumption of energy resources [1,2]. Since the stock of natural organic energy resources is limited, and in the future gas and oil will rise in price faster than coal and nuclear fuel, it should be expected that even power-consuming methods of hydrogen production, such as electrolysis, can successfully compete with traditional energy carriers in terms of unit cost. In this case, the economic effect increases in the case of a simultaneous solution of both technological and energy-ecological problems [3, 4].

New generation electrolysis equipment is easily adapted to the operating conditions of systems using renewable energy sources (RES) [5]. Therefore, of particular practical interest are energy-technological complexes (ETC) for producing $\mathrm{H}_{2}$ in high-pressure electrolyzers (HPE) as part of plants with solar photoelectric converters, since in this case, inverter systems designed to harmonize the parameters of the electrical energy generated according to the requirements of the electrolysis plant operation, are greatly simplified [6]. In some cases, they are completely excluded. This improves operational efficiency and reduces equipment costs. Solar energy storage systems, in particular the conversion of excess power into gas (for example, into hydrogen), are good for smoothing long-term roughness of solar insolation and energy consumption [7, 8]. Taking into account the trends and perspectives of world energy development, the search and development of scientific and technical solutions, design and operating parameters for highly efficient new-generation hydrogen generators operating under

(c) Rusanov A. V., Solovey V.V., Zipunnikov M. M., 2021 pressure, adapted to the operating conditions of solar power complexes, becomes an urgent problem $[9,10]$.

The combination of HPE with RES is necessary to smooth peak loads in the power system and ensure its stable operation during the day. At the same time, solar insolation is often used as a base load due to its wide availability [11, 12]. The direct use of RES in the power system is difficult due to the discrepancy between energy consumption and its production [13, 14]. Therefore, an urgent task is to develop electrolysis technologies for generating hydrogen with minimal electricity consumption, which can be integrated into autonomous energy complexes using RES (sun, wind) [15].

The modern level of hydrogen technologies, implemented, in particular, in electrolysis plants created at IPMach NAS of Ukraine, makes it possible to produce and accumulate $\mathrm{H}_{2}$ under high pressure without using compressor technology. A membrane-free process of electrochemical generation of hydrogen and oxygen under high pressure with the usage of non-deficient metals as electrode materials is developed [16, 17].

Purpose. The main purpose of the research is to determine the rational range of changes in the current density $(j)$ in a membrane-free monopolar HPE and to determine the effect of discrete power supply in order to analyze the possibility of its usage in conjunction with RES that are characterized by inconsistency of supply. To achieve this goal, it is necessary to determine the optimal range of changes in current densities and assess the effect of the operating characteristics of the electrolysis process for production of $\mathrm{H}_{2}\left(\mathrm{O}_{2}\right)$ when the electrolysis cell is de-energized against the background of the supplied load base continuous level. It is also necessary to investi- 
gate the electrochemical activity of the electrolysis cell when directly connected to a photoelectric converter (PEC).

Experimental results and their discussion. Comprehensive studies on the process of decomposition of water in alkaline electrolyte were carried out on an experimental stand (Fig. 1), which allows simulating the processes occurring in the main elements of the electrolysis cell. The experimental technique is described in [17, 18].

When implementing the proposed technology, the process of water decomposition proceeds continuously with the simultaneous release of $\mathrm{H}_{2}$ and $\mathrm{O}_{2}$. In the first half-cycle, hydrogen is evolved at the passive electrode $(08 \mathrm{X} 18 \mathrm{H} 10 \mathrm{~T})$ in gaseous form and is fed into the high-pressure line. At this time, $\mathrm{O}_{2}$ is chemically bound by the active electrode $\left(\mathrm{Fe}_{p}\right)$ (forming a chemical compound). On the next half-cycle, the active mass of $\mathrm{Fe}_{p}$ is electrochemically reduced by hydrogen with the release of oxygen at $08 \mathrm{X} 18 \mathrm{H} 10 \mathrm{~T}$ and its supply to the external line.

The process of $\mathrm{H}_{2}$ generation begins with the supply of a negative potential at $08 \mathrm{X} 18 \mathrm{H} 10 \mathrm{~T}$, with $\mathrm{Fe}_{p}$ acting as an anode. The half-cycle of $\mathrm{H}_{2}$ evolution is accompanied by an increase in voltage, and once the corresponding value of the potential difference is reached, the polarity in the electrolysis cell is switched. At the same time, the electromagnetic switch of the gas flow switches over. 08X18H10T becomes the anode, and $\mathrm{Fe}_{p}$ becomes the cathode. At the anode, gaseous $\mathrm{O}_{2}$ is released, and at the cathode, the active mass of $\mathrm{Fe}_{p}$ is restored. The gas flow switch shuts off the hydrogen line and opens the oxygen line, which prevents mixing of the gas flows. When the corresponding value of the potential difference is reached on the half-cycle of $\mathrm{O}_{2}$ evolution, the polarity of the electrodes is switched and the cycle is repeated.

To separate the gaseous phase from the liquid electrolyte, a special construction of separators with continuous monitoring of the liquid level is developed. The calculation of the cyclone-type separating devices is carried out using the results of mathematical modeling of gas dynamics in two-phase spatial flows [19, 20].

Analysis of the experimental data indicates that the 0.5$1.0 \mathrm{~V}$ region of the cyclogram of voltage variation on the $\mathrm{H}_{2}$ evolution half-cycle (Fig. 2) corresponds to the transition of ferrous iron $\mathrm{Fe}(\mathrm{II})$ to ferric $\mathrm{Fe}(\mathrm{III})$. On the half-cycle of $\mathrm{O}_{2}$ formation, $\mathrm{Fe}$ is electrochemically reduced. Electrical energy costs in the considered range of current densities are in the range of $3.9-4.1 \mathrm{~kW} \cdot \mathrm{h} / \mathrm{m}^{3}[17,18]$. At the same time, energy consumption by standard membrane electrolyzers (depending on the temperature and voltage of the process, the quality of electrodes, and a number of other factors) varies from 4.3 to $5.2 \mathrm{~kW} \cdot \mathrm{h} / \mathrm{m}^{3}$ of hydrogen $[1,5]$.

It was found that in the range of the change of $j=200$ $400 \mathrm{~A} / \mathrm{m}^{2}$ there is no increased gas filling in the interelectrode space, the presence of which can lead to a voltage drop in the

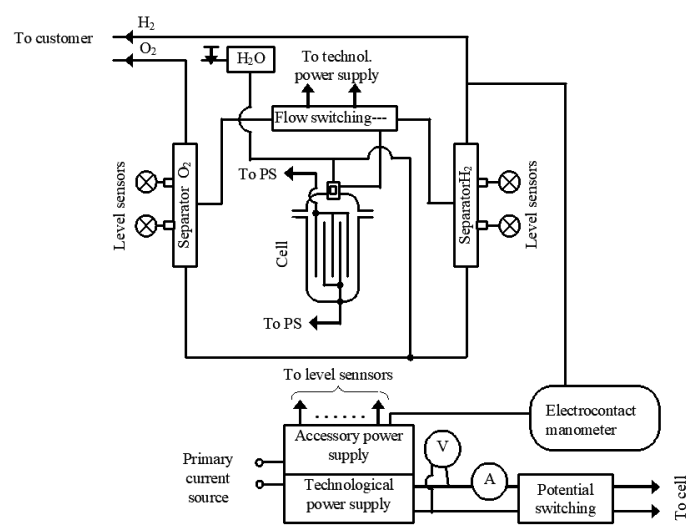

Fig. 1. Experimental stand with an electrochemical cell (PSpower supply unit)

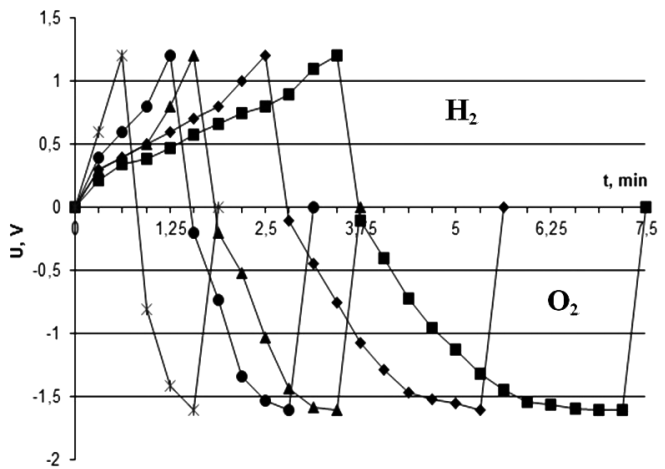

Fig. 2. Cyclogram of the change in the voltage of hydrogen and oxygen evolution during electrolysis with the usage of the electrode package 08X18H10T-Fe $\left(\right.$ at $\left.j=0.015 \mathrm{~A} / \mathrm{cm}^{2}\right)$ : $\times-600 \mathrm{~A} / \mathrm{m}^{2} ; \bullet-500 \mathrm{~A} / \mathrm{m}^{2} ; \mathbf{\Delta}-400 \mathrm{~A} / \mathrm{m}^{2} ; \bullet-300 \mathrm{~A} / \mathrm{m}^{2} ; \mathbf{-}-$ $200 \mathrm{~A} / \mathrm{m}^{2}$

electrolyte. In this case, the necessary conditions are provided for deeper redox reactions of the active mass of $\mathrm{Fe}_{p}$ in accordance with the equations

$$
\mathrm{Fe}+2 \mathrm{OH}^{-} \Leftrightarrow \mathrm{Fe}(\mathrm{OH})_{2}^{-}+2 e^{-}
$$

With prolonged operation of the active mass $\mathrm{Fe}_{p}$, a deeper oxidation of iron occurs

$$
\mathrm{Fe}(\mathrm{OH})_{2}+\mathrm{OH}^{-} \Leftrightarrow \mathrm{Fe}(\mathrm{OH})_{3}^{-}+e^{-}
$$

The voltage at which the start of $\mathrm{H}_{2}$ generation is recorded is significantly lower than the standard electrode potential of iron $(-0.44 \mathrm{~V})$, which is due to the redox process of $\mathrm{Fe}_{p}$ with the formation of the corresponding hydroxides $\left(\mathrm{Fe}(\mathrm{OH})_{2}\right.$, $\left.\mathrm{Fe}(\mathrm{OH})_{3}\right)$. The area of the developed gas absorption surface that is available for the electrolyte depends on the dispersion and structure of the metal. With an increase in the depth of penetration of the reaction front into the volume of the electrode mass, polarization during the oxidation of $\mathrm{Fe}_{p}$ is caused by a slowdown in the diffusion of $\mathrm{OH}^{-}$ions, while the diffusion rate decreases with an increase in the thickness of the layer of reacted iron. Therefore, when carrying out oxidation and reduction cycles, the amount of iron involved during electrolysis is determined by the depth of penetration of the reduction reaction into the volume of the active electrode. The deeper the chemical reaction penetrates into the $\mathrm{Fe}_{p}$, the greater the activation energy and the lower the rate of the electrochemical stage, which determines the rate of the electrolysis process and is the cause of the overvoltage, must be.

In order to optimize gas evolution and simplify the power supply system of the HPE, a number of experimental studies on the use of discrete power supply for the implementation of redox processes have been carried out. To search for ways to reduce the consumption of electrical energy and implement the oxidation process of $\mathrm{Fe}_{p}$ in the half-cycle of $\mathrm{H}_{2}$ formation, it was proposed to implement a discrete mode of current supply. The lack of data on the effect of cyclic power supply on the kinetics of redox reactions made it necessary to study these factors during the half-cycle of $\mathrm{H}_{2}$ formation during electrolysis decomposition of water.

Fig. 3 shows the cyclograms of the change in the release voltage of $\mathrm{H}_{2}$ and $\mathrm{O}_{2}$ with a discrete current supply on the hydrogen half-cycle. On the half-cycles of $\mathrm{O}_{2}$ formation, the power supply to the electrolysis cell is constant.

It was recorded that an increase in the de-energizing time from 1 to $3 \mathrm{~s}$ leads to a corresponding increase in the time of the oxidation process on the hydrogen half-cycle by 2.4 times, while the supply of electrical energy to the oxygen half-cycle was continuous. The total amount of $\mathrm{H}_{2}\left(\mathrm{O}_{2}\right)$ released on the corresponding half-cycles remained unchanged and amounted to $V_{\mathrm{H}_{2}}=15 \mathrm{ml} \quad\left(V_{\mathrm{O}_{2}}=7.5 \mathrm{ml}\right)$. 


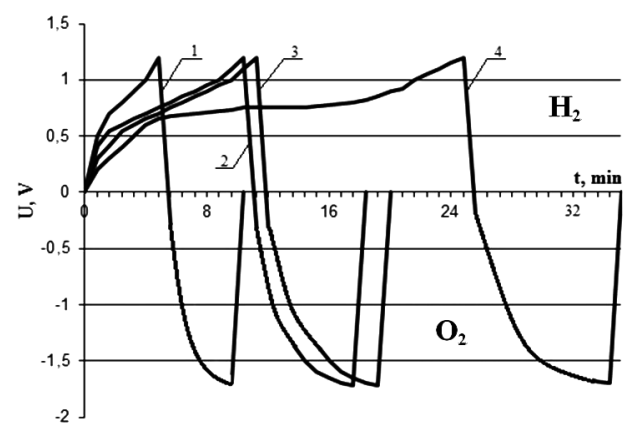

Fig. 3. The voltage change in the complete cycle of hydrogen and oxygen evolution during electrolysis with the usage of the electrode package 08X18H10T-Fe $\left(\right.$ at $\left.j=0.015 \mathrm{~A} / \mathrm{cm}^{2}\right)$ :

1 - continuous on both half-cycles; 2 - discrete on a hydrogen half-cycle for $1 \mathrm{~s}$ and de-energizing for $1 \mathrm{~s} ; 3$-discrete on a hydrogen half-cycle for $2 \mathrm{~s}$ and de-energizing for $2 \mathrm{~s} ; 4$-discrete on a hydrogen half-cycle for $1.5 \mathrm{~s}$ and de-energizing for $3 \mathrm{~s}$

The results of calculations of changes in enthalpy, voltage of the reactions of oxidation of the active mass at the anode $e_{a}$ and reduction at the cathode $e_{k}$, as well as the potential difference $E$ on the half-cycle of hydrogen evolution in the process of water electrolysis are presented in Table 1.

The electrochemical reactions on the electrodes are carried out only when a certain value of the potential difference is reached and are accompanied by an increase in voltage during intermittent supply of current to the electrolysis cell (Fig. 3). This circumstance causes additional losses in the electrolyzer and does not improve the energy characteristics of the process. But it makes it possible to supply electrical energy to the electrolyzer directly from RES (sun, wind) as part of the ETC and work through a switching-inverter unit or directly from a primary source of energy, characterized by inconsistency of supply. Fig. 4 shows a diagram of an autonomous wind power complex with HPE.

Fig. 5 shows the nature of the voltage variation for different levels of solar radiation in combination with typical polarization curves of alkaline water electrolyzer (active electrode area $10 \mathrm{~cm}^{2}$ ). The experiments were carried out with the direct connection of the electrolysis cell with a PEC (TOPRAY SOLAR) with a total surface $S=0.288 \mathrm{~m}^{2}$. The research results are shown in Table 2.

The average monthly amount of $\mathrm{H}_{2}$ evolved by the electrolysis cell, taking into account solar insolation from the PEC, is shown in Fig. 6. The connection of the electrolyzer to the PEC was carried out without secondary converters.

Fig. 7 shows the current-voltage characteristics of the photoelectric system at various levels of solar radiation

The characteristics of alkaline water electrolyzer (curve 7) deviate from curve 6 . Therefore, the used PEC fully provides the maximum power of the electrolysis cell.

The intersections of curve 7 with curves 1-5 (Fig. 7) determine the possible operating points of the electrolysis cell with a photoelectric converter. For the efficient operation of the electrolyzer (curve 7), the distance to the level corresponding to the maximum power of the PEC (curve 6) must be mini-

Table 1

Change in the voltage of the reactions on electrodes

\begin{tabular}{|l|c|c|c|}
\hline \multicolumn{1}{|c|}{ Reaction on electrodes } & $e_{a}, \mathrm{~V}$ & $e_{k}, \mathrm{~V}$ & $E, \mathrm{~V}$ \\
\hline $\mathrm{Fe}+2 \mathrm{OH}^{-} \Leftrightarrow \mathrm{Fe}(\mathrm{OH})_{2}+2 e^{-}$ & 0.56 & - & 1.044 \\
\hline $\mathrm{Fe}(\mathrm{OH})_{2}+2 e^{-} \Leftrightarrow 2 \mathrm{OH}^{-}+\mathrm{Fe}$ & - & 0.56 & - \\
\hline $\mathrm{Fe}(\mathrm{OH})_{2}+\mathrm{OH}^{-} \Leftrightarrow \mathrm{Fe}(\mathrm{OH})_{3}^{-}+e^{-}$ & 1.05 & - & 1.6 \\
\hline $\mathrm{Fe}(\mathrm{OH})_{3}+e^{-} \Leftrightarrow \mathrm{Fe}(\mathrm{OH})_{2}+\mathrm{OH}^{-}$ & - & 1.05 & - \\
\hline
\end{tabular}

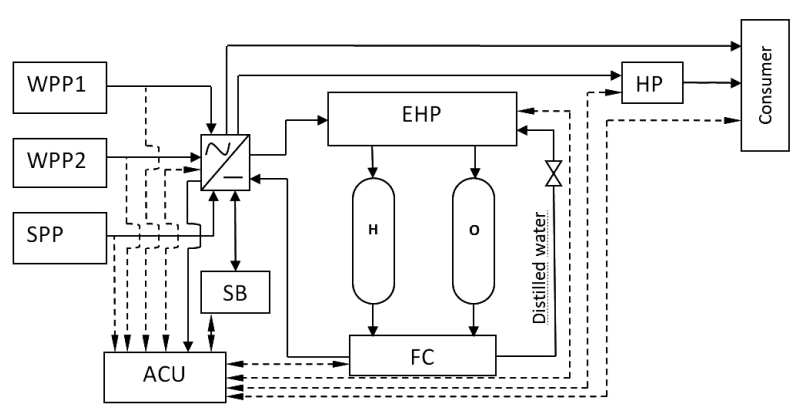

Fig. 4. Scheme of an autonomous wind power complex with a high-pressure electrolyzer:

$S B$ - storage battery; $A C U$ - automatic control unit; WPP1, WPP2 - wind power plant; SPP - solar power plant; HP - heat pump; FC - fuel cell; EHP - high pressure electrolyzer; switching inverter unit

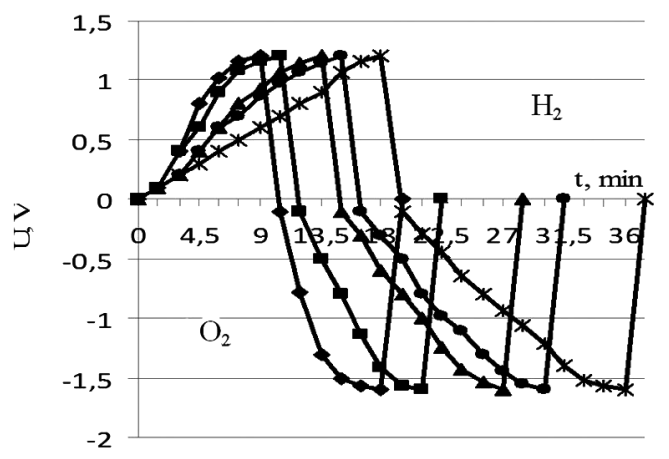

Fig. 5. Changes in the voltage of the complete cycle of hydrogen and oxygen evolution during electrolysis for different levels of solar radiation:

- - June (5.46 kW. h/m²/day); - September (3.49 $\mathrm{kW} \times$ $\times h / \mathrm{m}^{2} /$ day $) ; \boldsymbol{\Delta}-$ March $\left(3.05 \mathrm{~kW} \cdot \mathrm{h} / \mathrm{m}^{2} /\right.$ day $) ; \bullet-$ November $\left(1.19 \mathrm{~kW} \cdot \mathrm{h} / \mathrm{m}^{2} /\right.$ day $) ; \times-$ December $\left(0.9 \mathrm{~kW} \cdot \mathrm{h} / \mathrm{m}^{2} /\right.$ day $)$

mal, which ensures the highest energy consumption. At the same time, the excess electrical energy from the PEC increases the reliability and stability of the electrolysis system.

While ensuring the specified performance of the electrolysis system, the increase in time of the complete gas evolution cycle $\left(\mathrm{H}_{2}\right.$ and $\left.\mathrm{O}_{2}\right)$ depends on the season and increases approximately by 2 times from June to December. A decrease in the duration of the hydrogen and oxygen gas evolution cycles indicates an increase in the current density (i.e., an increase in the power supply from the PEC) with an increase in solar in-

Table 2

Electrochemical activity of the electrode assembly 08X18H10T-Fe ${ }_{p}$ depending on the current density when directly connected to the PEC

\begin{tabular}{|c|c|c|c|c|c|}
\hline 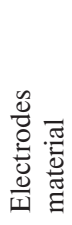 & 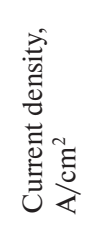 & 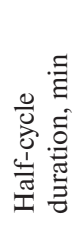 & 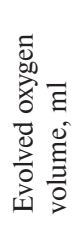 & 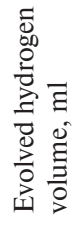 & 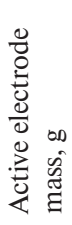 \\
\hline \multirow{5}{*}{ 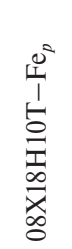 } & 0.0255 & 9 & 15 & 30 & \multirow[t]{5}{*}{13.6} \\
\hline & 0.0227 & 11 & 13.5 & 27 & \\
\hline & 0.017 & 14 & 12 & 24 & \\
\hline & 0.011 & 16 & 11 & 22 & \\
\hline & 0.0057 & 18 & 8 & 16 & \\
\hline
\end{tabular}




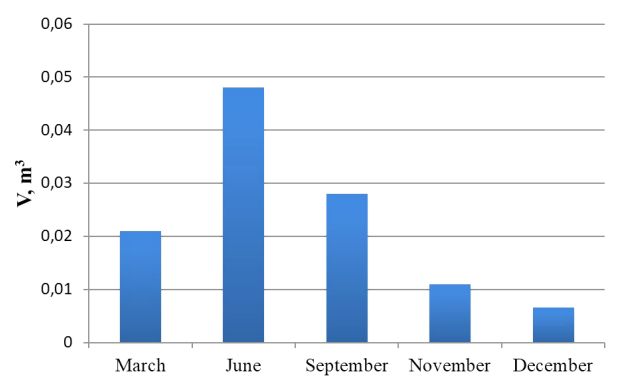

Fig. 6. Average monthly amount of hydrogen evolved by the electrolysis cell, taking into account solar insolation from the PEC with a total surface $S=0.288 \mathrm{~m}^{2}$

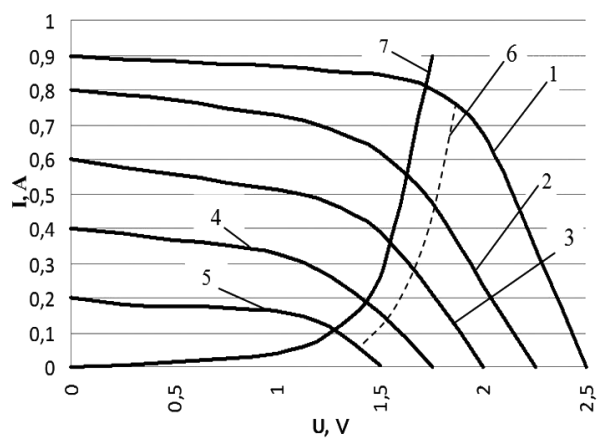

Fig. 7. Current-voltage characteristic of the photoelectric system at different levels of solar insolation:

1 - June $(47.2 \mathrm{~kW} \cdot \mathrm{h}) ; 2$ - September $(30.2 \mathrm{~kW} \cdot \mathrm{h}) ; 3$ - March $(26.35 \mathrm{~kW} \cdot \mathrm{h}) ; 4$ - November $(10.28 \mathrm{~kW} \cdot \mathrm{h}) ; 5$ - December $(7.77 \mathrm{~kW} \cdot \mathrm{h}) ; 6$ - maximum power of the solar panel; 7 - currentvoltage characteristic of alkaline electrolyzer

solation in the summer. With a decrease in solar insolation, an increase in the half-cycles of hydrogen and oxygen evolution occurs.

The irregular primary flow of solar radiation, that is, the volatility of power generation that is generated by the PEC, is compensated in the electrolyzer due to the internal capacitive nature of the electrical resistance of the electrode pairs, which is not sensitive to the quality of the power supply. Obviously, this approach is appropriate for the creation of autonomous power supply units of small and medium power.

Electrolysis equipment of a new generation is easily adapted to the operating conditions of systems using renewable energy sources. Therefore, ETC are of particular practical interest for producing $\mathrm{H}_{2}$ in high-pressure electrolyzers as part of plants with photoelectric solar converters, since in this case inverter systems, designed to bring the parameters of generated electrical energy into compliance with the power supply requirements of the electrolysis installation, which improves operational efficiency and reduces equipment costs, are greatly simplified, and in some cases, completely excluded.

Conclusions. The optimal range of current density variation in a membrane-free high-pressure electrolyzer in the range of $200-400 \mathrm{~A} / \mathrm{m}^{2}$ has been established experimentally. In this case, a deeper redox process of the active mass of the iron electrode is carried out. Electrical energy consumption in the considered range of current densities is in the range of $3.9-4.1 \mathrm{~kW} \cdot \mathrm{h} \mathrm{m}^{3}$.

The supply of electrical energy in a discrete mode leads to an increase in the time of the electrolysis cell de-energizing from 1 to $3 \mathrm{~s}$, which leads to a corresponding increase in the time of the oxidation process by 2.4 times, while the total amount of hydrogen (oxygen) released on the corresponding half-cycles remains unchanged $V_{\mathrm{H}_{2}}=15 \mathrm{ml} \quad\left(V_{\mathrm{O}_{2}}=7.5 \mathrm{ml}\right)$.

The obtained theoretical values of voltages (1.044$1.6 \mathrm{~V}$ ) of electrochemical reactions of water decomposition in alkaline electrolyzer make it possible to determine the physical nature of the appearance of characteristic flat areas on the experimental cyclograms of the potential difference change. The voltage at which the start of hydrogen generation is recorded is significantly lower than the standard electrode potential of iron $(-0.44 \mathrm{~V})$ in the reaction of water decomposition during electrolysis, which is due to the redox process of the iron electrode with the formation of the corresponding hydroxides $\left(\mathrm{Fe}(\mathrm{OH})_{2}, \mathrm{Fe}(\mathrm{OH})_{3}\right)$. The influence of discrete power supply of the electrolyzer is studied experimentally.

The electrochemical reactions on the electrodes are carried out only when a certain voltage value is reached and are accompanied by an increase in the potential difference with an intermittent supply of current to the electrolyzer. This makes it possible to supply electrical energy to the electrolyzer directly from the primary energy source (sun, wind) as part of the energy technology complex.

The work was carried out at the expense of budgetary program No. 341 "Development of scientific foundations for the production, storage and use of hydrogen in autonomous power supply systems".

\section{References.}

1. Paidar, M., Fateev, V., \& Bouzek, K. (2016). Membrane electrolysis - history, current status and perspective. Electrochimica Acta, 209, 737-756. https://doi.org/10.1016/j.electacta.2016.05.209.

2. Esposito, Daniel V. (2017). Membraneless Electrolyzers for Low-Cost Hydrogen Production in a Renewable Energy Future. International Journal of Hydrogen Energy, 1(4), 651-658. https://doi.org/10.1016/j.joule.2017.11.013.

3. Dawood, F., Anda, M., \& Shafiullah, G. M. (2020). Hydrogen production for energy: An overview. International Journal of Hydrogen Energy, 45, 3847-3869. https://doi.org/10.1016/j. ijhydene.2019.12.059.

4. Julie C. Fornaciari, Michael R. Gerhardt, Jie Zhou, Yagya N. Regmi, Nemanja Danilovic, Alexis T. Bell, \& Adam Z. Weber (2020). The Role of Water in Vapor-fed Proton-ExchangeMembrane Electrolysis. Journal of The Electrochemical Society, 167(10), 104508. https://doi.org/10.1149/1945-7111/ ab9b09.

5. O’Neil, G.D., Christian, C.D., Brown, D.E., \& Esposito, D. V. (2016). Hydrogen production with a simple and scalable membraneless electrolyzer. Journal of the Electrochemical Society, 163, F3012-F3019.

6. Amikam, G., Nativ, P., \& Gendel, Y. (2018). Chlorine-free alkaline seawater electrolysis for hydrogen production. International Journal of Hydrogen Energy, 43, 6504-6514. https:// doi.org/10.1016/j.ijhydene.2018.02.082.

7. Kies, A., Schyska, B. U., \& Bremen Von, L. (2016). Curtailment in a highly renewable power system and its effect on capacity factors. Energies, 9, 1-18. https://doi.org/10.3390/ en9070510.

8. Grigoriev, S.A., Fateev, V. N., Bessarabov, D. G., \& Millet, P. (2020). Current status, research trends, and challenges in water electrolysis science and technology. International Journal of Hydrogen Energy, 45(49), 26036-26058. https://doi. org/10.1016/i.iihydene.2020.03.109.

9. Phillips, R., \& Dunnill, C. (2016). Zero gap alkaline electrolysis cell design for renewable energy storage as hydrogen gas. RSC Advances, 6(102), 100643-100651. https://doi. org/10.1039/C6RA22242K.

10. Xiang, C., Papadantonakis, K. M., \& Lewis, N. S. (2016). Principles and implementations of electrolysis systems for water splitting. Materials Horizons, 3, 169-173. https://doi. org/10.1039/C6MH00016A.

11. Aminov, R.Z., Bairamov, A.N., \& Garievskii, M.V. (2019). Assessment of the Performance of a Nuclear-Hydrogen Power Generation System. Thermal Engineering, 66(3), 196-209. https://doi.org/10.1134/S0040601519030017. 
12. Aminov, R. Z., Shkret, A. F., \& Garievskii, M.V. (2016). Estimation of lifespan and economy parameters of steam-turbine power units in thermal power plants using varying regimes. Thermal Engineering, 63, 551-557. https://doi. org/10.1134/S0040601516080012.

13. Rakousky, C., Reimer, U., Wippermann, K., Kuhri, S., Carmo, M., Lueke, W., \& Stolten, D. (2017). Polymer electrolyte membrane water electrolysis: Restraining degradation in the presence of fluctuating power. Journal of Power Sources, $342,38-47$

14. Aminov, R.Z., Bairamov, A.N., \& Garievskii, M.V. (2020). Estimating the system efficiency of the multifunctional hydrogen complex at nuclear power plants. International Journal of Hydrogen Energy, 45(29), 14614-14624. https://doi. org/10.1016/j.ijhydene.2020.03.187.

15. Phillips, R., Edwards, A., Rome B., Jones, D. R., \& Dunnill, C.W. (2017). Minimising the ohmic resistance of an alkaline electrolysis cell through effective cell design. International Journal of Hydrogen Energy, 42, 23986-23994.

16. Zipunnikov, M. M. (2019). Formation of potassium ferrate in a membrane-less electrolysis process of water decomposition. Issues of Chemistry and Chemical Technology, 1, 42-47. https://doi.org/10.32434/0321-4095-2019-126-5-42-47.

17. Shevchenko, A. (2020). Creation of autonomous and network energy-technological complexes with a hydrogen storage of energy. Vidnovliuvana Energetika, 61(2), 18-27. https://doi. org/10.36296/1819-8058.2020.2(61).18-27.

18. Solovey, V. V., Khiem, N. T., Zipunnikov, M. M., \& Shevchenko, A. (2018). Improvement to the Membrane-less Electrolysis Technology for Hydrogen and Oxygen Generation. French-Ukrainian Journal of Chemistry, 6(2), 73-79. https:// doi.org/10.17721/fujcV6I2P73-79.

19. Rusanov, A., Rusanov, R., \& Lampart, P. (2015). Designing and updating the flow part of axial and radial-axial turbines through mathematical modelling. Open Engineering (formerly Central European Journal of Engineering), 5, 399-410. https://doi.org/10.1515/eng-2015-0047.

20. Rusanov, A. V., Solovey, V.V., \& Lototskyy, M. V. (2020). Thermodynamic features of metal hydride thermal sorption compressors and perspectives of their application in hydrogen liquefaction systems. Journal of Physics: Energy, 2(2), 10. https://doi.org/10.1088/2515-7655/ab7bf4.

\section{Удосконалення безмембранного електролізного процесу отримання водню й кисню}

\section{А. В. Русанов, В. В. Соловей, М. М. Зіпунніков}

Інститут проблем машинобудування імені А. М. Підгорного НАН України, м. Харків, Україна, e-mail: zipunnikov_n@ukr.net

Відновлювані джерела енергії забезпечують нестабільний потік енергії до установок автономного енергетичного комплексу. Тому, щоб використовувати електролізер в якості елемента комплексу, що розглядається, необхідно визначити оптимальний діапазон зміни густини струму та оцінити вплив робочих характеристик процесу електролізу на виділення газу $\mathrm{H}_{2}\left(\mathrm{O}_{2}\right)$, коли електроживлення електролізера вимкнено на $1-3$ секунди на тлі безперервного базового рівня струму.

Мета. Основною метою досліджень є визначення раціонального діапазону зміни густини струму, що подається на монополярний безмембранний електролізер високого тиску, а також визначення впливу дискретної подачі струму при електролізі на електрохімічні реакції.

Методика. Комплексні дослідження електрохімічних процесів розкладання води в лужному електроліті 3 утворенням водню та кисню в експериментальній уста- новці, що дозволяє циклічно подавати електричне живлення на електролізер з візуальним контролем зазначених процесів.

Результати. Розглянута технологія циклічного генерування водню й кисню, що виключає необхідність використання розділових іонообмінних мембран. Встановлено раціональний діапазон зміни щільності струму на безмембранному монополярному електролізері високого тиску з використанням електродів, виготовлених із металів зі змінною валентністю. Визначено вплив дискретної подачі електричної енергії на електролізну комірку в залежності від електрохімічних реакцій, що протікають на активному залізному електроді. Розраховані теоретичні значення напруги протікання реакцій окислювання й відновлення активної маси залізного електрода, а також напруга на напівциклі виділення водню у процесі електролізу води.

Наукова новизна. Збільшення періоду відключення живлення 31 до 3 с призводить до відповідного збільшення часу процесу окислення на напівциклі виділення водню у 2,4 рази. Але загальна кількість водню (кисню), що виділяється на відповідних напівциклах, залишається незмінною і становить $V_{\mathrm{H}_{2}}=15$ мл $\left(V_{\mathrm{O}_{2}}=7.5\right.$ мл).

Практична значимість. Оптимальний діапазон щільності струму для роботи безмембранного електролізера високого тиску знаходиться в межах 200-400 A/s². За таких умов відбувається найактивніший окислювальновідновлювальний процес активної маси залізного електрода. Споживання електроенергії в цьому випадку зна-

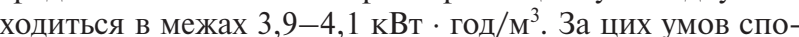
живання енергії стандартними мембранними електролізерами (у залежності від температури та тиску процесу, якості електродів і ряду інших факторів) варіюється від

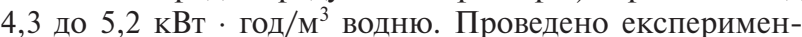
тальне вивчення впливу дискретного живлення електролізера на його здатність до газоутворення. Це дає можливість поставляти електричну енергію на електролізну комірку безпосередньо від первинного джерела енергії (сонце, вітер) у складі енерготехнологічного комплексу.

Ключові слова: електролізер, водень, кисень, електрохімічна реакція, струм, електрод

\section{Усовершенствование безмембранного электролизного процесса получения водорода и кислорода}

\section{А. В. Русанов, В. В. Соловей, Н. Н. Зипунников}

Институт проблем машиностроения имени А. М. Подгорного НАН Украины, г. Харьков, Украина, e-mail: zipunnikov_n@ukr.net

Возобновляемые источники энергии обеспечивают нестабильной поток энергии к установкам автономного энергетического комплекса. Поэтому, чтобы использовать электролизер в качестве элемента рассматриваемого комплекса, необходимо определить оптимальный диапазон изменения плотности тока и оценить влияние рабочих характеристик процесса электролиза на выделение $\mathrm{H}_{2}\left(\mathrm{O}_{2}\right)$, когда электропитание электролизера отключено на 1-3 секунды на фоне непрерывного базового уровня тока.

Цель. Основной целью исследований является определение рационального диапазона изменения плотности тока, подаваемого на монополярный безмембранный электролизер высокого давления, а также определение влияния дискретной подачи тока при электролизе на электрохимические реакции.

Методика. Комплексные исследования электрохимических процессов разложения воды в щелочном элек- 
тролите с образованием водорода и кислорода в экспериментальной установке позволяют циклически подавать электропитание на электролизер с визуальным контролем рассматриваемых процессов.

Результаты. Рассмотрена технология циклического генерирования водорода и кислорода, что исключает необходимость использования разделительных ионообменных мембран. Установлен рациональный диапазон изменения плотности тока на безмембранном монополярном электролизере высокого давления с использованием электродов, изготовленных из металлов с переменной валентностью. Определено влияние дискретной подачи электрической энергии на электролизную ячейку в зависимости от электрохимических реакций, протекающих на активном железном электроде. Рассчитаны теоретические значения напряжения протекания реакций окисления и восстановления активной массы железного электрода, а также напряжение на полуцикле выделения водорода в процессе электролиза воды.

Научная новизна. Увеличение времени обесточивания от 1 до 3 с приводит к соответствующему росту времени окислительного процесса на водородном полуцикле в 2,4 раза. При этом общее количество водорода (кислорода), выделившегося на соответствующих полу- циклах, остается неизменным и составляет $V_{\mathrm{H}_{2}}=15$ мл $\left(V_{\mathrm{O}_{2}}=7.5\right.$ мл).

Практическая значимость. Оптимальный диапазон плотности тока для работы безмембранного электролизера высокого давления находится в пределах 200-400 A/ $\mathrm{m}^{2}$. При таких условиях происходит интенсивный окислительно-восстановительный процесс активной массы железного электрода. Потребление электроэнергии в этом случае находится в пределах 3,9-4,1 кВт · ч/м³. При этом потребление энергии стандартными мембранными электролизерми (в зависимости от температуры и давления процесса, качества электродов и ряда других факторов) варьируется от 4,3 до 5,2 кВт · ч/м ${ }^{3}$ водорода Проведено экспериментальное изучение влияния дискретного питания электролизера на его способность к газообразованию. Это дает возможность поставлять электрическую энергию на электролизную ячейку непосредственно от первичного источника энергии (солнце, ветер) в составе энерготехнологического комплекса.

Ключевые слова: электролизер, водород, кислород, электрохимическая реакция, ток, электрод

Recommended for publication by O.L. Shubenko, Doctor of Technical Sciences. The manuscript was submitted 25.07.20. 